\title{
Decentralized Power Control Strategy in Microgrid for Smart Homes
}

\author{
Manzar Ahmed $^{1 *}$, Asif Nawaz ${ }^{2}$, Mishaal Ahmed ${ }^{3}$, Muhammad Shoaib Farooq $^{3}$ \\ ${ }^{1}$ Punjab Institute of Complementary Sciences, Lahore, Pakistan \\ ${ }^{2}$ Higher College of Technology, Dubai, UAE \\ ${ }^{3}$ University of Technology \& Management, Lahore, Pakistan \\ Email: *azaki786@yahoo.com, anawaz@hct.ac.ae, mishaalahmed242@gmail.com, shoaib.farooq@umt.edu.pk
}

How to cite this paper: Ahmed, M., Nawaz, A., Ahmed, M. and Farooq, M.S. (2019) Decentralized Power Control Strategy in Microgrid for Smart Homes. Smart Grid and Renewable Energy, 10, 43-53. https://doi.org/10.4236/sgre.2019.103004

Received: November 28, 2018

Accepted: March 26, 2019

Published: March 29, 2019

Copyright (c) 2019 by author(s) and Scientific Research Publishing Inc. This work is licensed under the Creative Commons Attribution International License (CC BY 4.0).

http://creativecommons.org/licenses/by/4.0/

\begin{abstract}
In this paper, Nanogrid System and working is presented for the future sustainable power system. This system is for small scale for smart homes with decentralized power system. A Nanogrid is the combination of energy system such as using of sources such as solar cells, fuel cells, micro turbines, wind turbines, energy storage devices and AC, DC power systems and controllable loads. This grid may use single mode or island mode with soft switching. The Dynamic of power system capability increases reliability, in case if one system fails it switch to other system to continue proving electric power with losing quality. The energy storage system is used to maintain stability during transition between the operating modes is emphasized. The Simulink model is used to present the working of system.
\end{abstract}

\section{Keywords}

Microgrid, Distributed Generation (DG) Load Sharing, In-Landing and n Gird

\section{Introduction}

There are two types of Power generation control systems for the grid such as centralized and distributed generation. Its mean power can be generated from the one big source such from big dams in case of hydropower system. In Pakis$\tan$, the major source of electricity generation is hydro. These are centralized power system and not feasible for future power supply system because if this major source fails then no other source of electricity available for us and its all depend on fault clearance time. Also there are many issues regarding this system such as initial cost, maintenance factor and power loss and power balancing is- 
sues. In decentralized power system, we have chosen to use alternative power system such as renewable energy system with main power source such as hydro, nuclear and oil gas generators. These systems can be divided into two categories such as conventional and non-conventional power systems. This system is called micro grid or micro power system. In micro grid, we have also both type of power system AC and DC system. Further, we can divide this micro power system into small areas called Nanogrid. In future power system, we need both power system at both level AC and DC because there will be many applications related to DC power such as car charging. In Nano grid, we may have both options depend on the customer demand. But at present, we proposed this grid with DC power system in research. We used DC power system because losses are reduced and we do not need inverter.

In Pakistan, we need to install nano grid due to the shortage of electricity and load shading problem in all over the country. Nanogrids can be installed in village and rural areas where load shading is more than 8 hours daily. Nanogrids can support small loads in these areas and these grids in form of clusters can provide electricity at cheap rate.

One big advantage is for Nano grid is that these grids can operate in-landing mode or they can be connected to micro grid or both options can be used AC or DC [1]. The blockdiagram of the Nano grid functioning is shown in Figure 1.

The Micro grids are used for large power system and also provide electricity to small grids. Sustainable systems in the sense that they endure are resilient systems. The Nanogrid system has the following advantages as follow:

1) Higher efficiency, and less volume and footprint also supports resiliency.

2) Distributed generation leads to a de-centralized control architecture.

3) Distributed generation adds active elements which support independent control strategies.

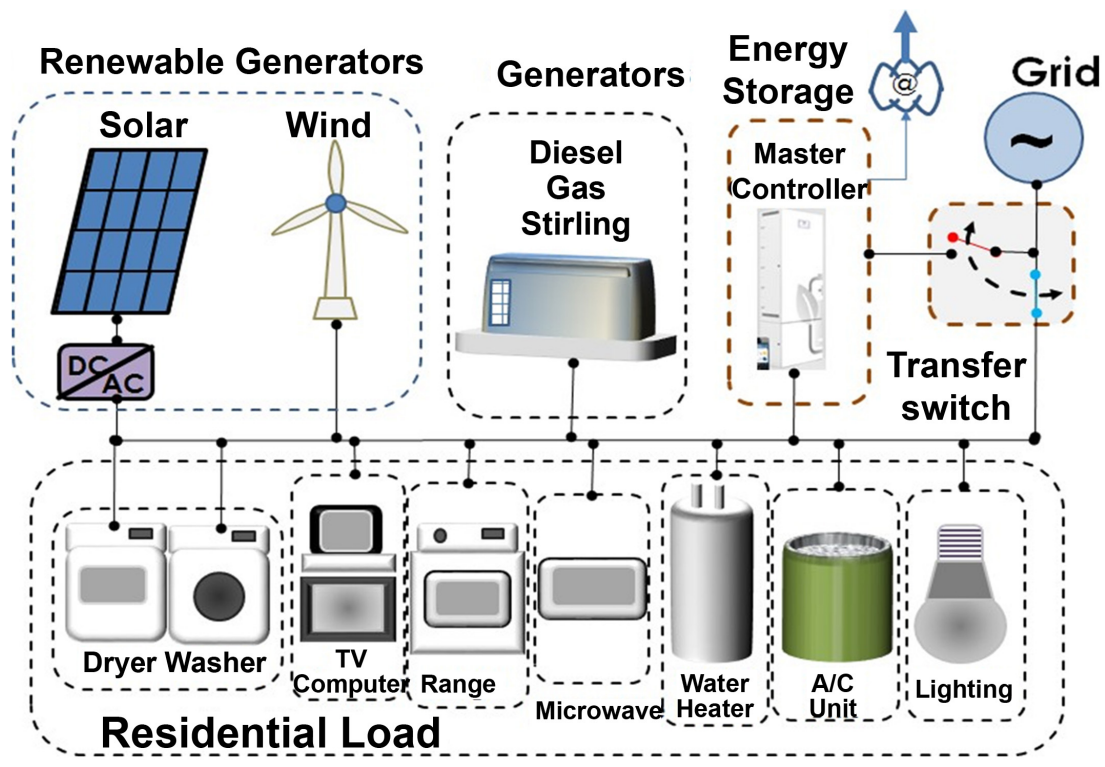

Figure 1. Functional concept of Nano grid. 
4) This system requires diverse power inputs because each distributed generation technology has worst availability than the grid.

\section{Feature of Nanogrids}

The Nano-grid means small size grid or power supply system such as for building, factory and rural areas as compared to the micro grid. The small load may be the no of houses such as colony or a hosing scheme in which there may be group of $50-100$ houses with the area diameter may be less than $500 \mathrm{~m}$. This system can be used for agricultural system or irrigation. Its mean the small loads can be in form of clusters. In villages the capacity of the system me be 1.5 to 3 $\mathrm{kW}$ with PV system and more depend on the system in used. The power is distributed in small clusters a short radius of each cluster may be $230-250 \mathrm{~m}$ in range [2]. The system is working at 48 volt $\mathrm{DC}$ and system with dc converter with output 220 Volt DC and can convert to AC to DC conversion 220V. For billing system customer can use smart card or can use prepaidoption.

\section{Issues to Beaddressed}

There are problems related with the Nano grid given below;

1) Efficient Energy storage system.

2) Converters.

3) Switching problems.

4) Interconnection \& energy management.

5) Power control.

6) Communication between Nanogrids and Macrosystems.

\section{Proposed Solution}

The followings are the proposed solution to the above issues in the Nano grids.

\subsection{Energy Storage System for Nino Grid}

In Nano grid we need an efficient battery storage system to store energy system and efficient converters. The lithium batteries are highly efficient and cheap in cost. The some popular lithium batteries are Lead Acid, Nickel Cadmium and Lithium-ion; there are three types' lithium batteries such as;

1) Cobalt oxide $\mathrm{LiCoO}_{2}$

2) Oxide manganese $\mathrm{LiMn}_{2} \mathrm{O}_{4}$

3) Iron-Phosphate $\mathrm{LiFePO}_{4}$

Above batteries are proposed for future grids. In Table 1(a) and Table 1(b), all types of batteries are given with power rating below. The life time and efficiency of the batteries can be enhanced by Nanocoating.

\subsection{Converters for Proposed System}

In Micro and Nano grids we need efficient converters to convert power from DC to AC, AC to DC and DC to DC. These types of Converters should be efficient 
Table 1. (a) Types of the batteries with power rating; (b) Types of the batteries with efficiency and life time.

(a)

\begin{tabular}{ccccc}
\hline $\begin{array}{c}\text { Type of energy } \\
\text { storage }\end{array}$ & $\begin{array}{c}\text { Power density PDr } \\
\text { (W/kg) }\end{array}$ & $\begin{array}{c}\text { Energy density EDr } \\
\text { (Wh/kg) }\end{array}$ & $\begin{array}{c}\text { Power level } \\
\text { MW }\end{array}$ & Time (hours) \\
\hline Ultra capacitor & 20000 & 30 & $<1$ & $10 / 3600$ \\
Lithium-ion battery & $300-800$ & $150-250$ & $<1$ & 4 \\
lead acid battery & $200-400$ & $25-30$ & $0.001-10$ & 4 \\
Fly wheel & $150-3000$ & $5-80$ & $0.1-10$ & 0.25 \\
Flow battery & $5-40$ & $90-400$ & $0.01-100$ & 4 \\
\hline
\end{tabular}

(b)

\begin{tabular}{cccc}
\hline Type of energy storage & Efficiency & Life time 20 years & SOC $^{-1}$ factor \\
\hline Ultra capacitor & $99 \%$ & none & 0.9 \\
Lithium-ion battery & $96 \%$ & $1-2$ & 0.3 \\
lead acid battery & $75 \%$ & $4-6$ & 0.5 \\
Fly wheel & $93 \%$ & maintenance & 1 \\
Flow battery & $80 \%$ & unknown & 1 \\
\hline
\end{tabular}

and may be operating in one direction or bi-directional. Dual directional DC-DC converters used as to interface between storage modules may be lithium battery and other used for DC bus or it may use with DC bus to connect with other DC system to link the energy storage. The efficient converter diagram is given for Nanogrid is given in Figure 2.

For bidirectional DC-DC converters we used the advanced power MOSFET (Metal Oxide Semiconductor Field Effect Transistor) and IGBT (Insulated Gate Bipolar Transistor) [3].

\subsection{Soft-Switching for Increased Efficiency}

Speed of the switches should be very fast to reduce the delay and these switches should be programmed by software. The old electronic switches were slow and produced delay in systems. If main power trip offs the system should be switch to next available power system quickly. There should be very short delay time between switching to other positions. The soft switching is very efficient and used for medium voltage and frequency. Such as for solid-state transformers. The major advantage of the soft switching is programming can be used to used the switch. This switch has polar-transistor (IGBT)-based resonant dual active bridges. The switching loss reduction identified as:

1) It shape the conducted current.

2) Work on zero-voltage-switching (ZVS) for tuning instrument.

It can be seen from above these switches are very useful in micro and nano grids these are verified with a $1.7-\mathrm{kV}$ IGBT-based neutral-point-clamped bridge. These are highly efficient and can be programmed. 


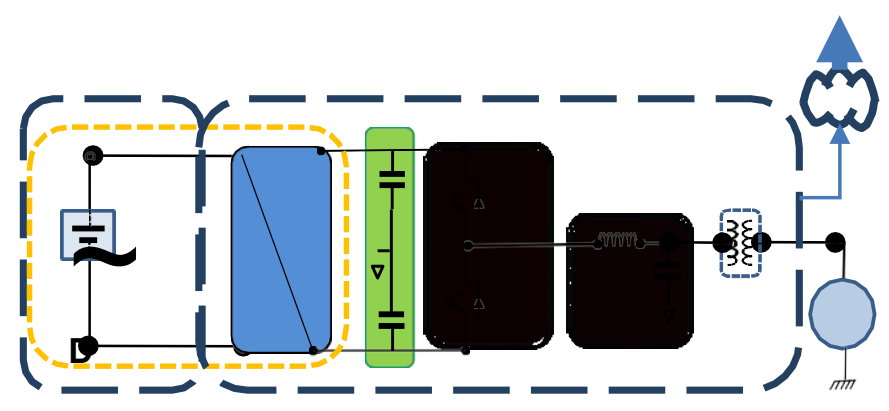

Figure 2. Power Converter for Nanogrid storage.

\subsection{Energy Management in Energy Storage DC Nano-Grid}

In energy storage DC Nano-grid (ESNG), energy management is needed to make sure:

1) The storage devices are working properly,

2) prepare in advance power and energy for coming demands so that no power is wasted,

3) to improve overall energy efficiency of ESNG,

4) to extend lifetime of battery-based EnSDs in ESNG.

The energy storage device should have charging rate discharge rate. For example, lead-acid battery should work SOC above $20 \%$ for safety. The charging and discharging rate should not above manufacturers mention. On other hand barratry life span will be reduced due heat and reactions. So, all constraints of EnSDs in ESNG have to be strictly complied.

The EnSDs also need information in advance for demand of energy to ensure availability and high performance of ESNG. For example, when there is redundant energy, the EnSDs have to charge sufficiently. Otherwise, they may have insufficient power to meet load demands later on, resulting in bus voltage drops and poor performance. On the other side, the EnSDs have to discharge properly before excess power is present. Otherwise, they may not be able to charge the excess power. Thus, part of or the whole excess power has to be wasted.

\subsection{Energy Availability and Efficiency Calculation}

To evaluate availability of ESNG energy, Energy Availability (EAI) is proposed and calculated as:

$$
E(\%)=\left(1-\frac{E_{\text {fail }}}{E_{\text {demand }}}\right) \times 100 \%
$$

where:

$E_{\text {fail }}$ is energy supply failure,

$E_{\text {demand }}$ customer energy requirement The energy efficiency $\left(\varepsilon_{\mathrm{e}}\right)$, Conversion efficiency $\left(\varepsilon_{\mathrm{e} \_ \text {conv }}\right)$ Energy storing efficiency $\left(\varepsilon_{\mathrm{e} \_ \text {store }}\right)$

If Energy is converted to one form to another form such as AC to DC the efficiency can be calculated in form of loss energy loss in one cycle and energy loss over internal resistance of the EnSD in charge discharge time. 
Energy storing efficiency refers to energy loss due to self-discharge and other losses of EnSD. Energy efficiency can be expressed as:

$$
\varepsilon_{e}=\varepsilon_{\text {e_conv }}-\varepsilon_{\text {e_store }}
$$

Energy conversion efficiency can be calculated based on power conversion efficiency $\varepsilon_{\mathrm{p}_{-} \text {conv }}$ over time:

$$
\varepsilon_{\text {e_conv }}=\frac{1}{t_{\text {end }}-t_{\text {start }}} \int_{t_{\text {satrt }}}^{t_{\text {end }}} p-\operatorname{convd} t
$$

Energy storing efficiency can be calculated based on self-discharge rate (D) of the energystorage:

$$
\varepsilon_{\text {eco }}=1-\mathrm{D} t_{\text {stored }}
$$

where $t_{\text {stored }}$ time that the energy is stored Energy management is needed to improve energy efficiency of ESNG. The system is Figure 3.

In ESNG, lifetime of battery-based EnSDs is short because they have limited cycle life compared to other energy storage technologies. Cycle life of EnSD indicates number of charge/discharge cycles before the EnSD fails. For battery-based EnSD, cycle life reduces exponentially when depth-of-discharge (DOD) increases.

So, the energy distribution in ESNG is should be done carefully to control the losses.

In actual implementation, a monitoring instrument is installed for example with battery a device is equipped as Battery Monitoring [4]. The provides:

1) Voltage, temperature and current,

2) Protection information regarding over-current, over/under-voltage,

3) Temperature control and pressure information,

4) Power information in SOC of cells.

\section{Energy Storage DC Nano-Grid in Residential Micro-Grid}

In this section, the ESNG used in a residential micro-grid is investigated. The residential micro grid has renewable energy sources as solar photo-voltaic and wind energy [5]. Besides renewable energy sources, the residential micro-grid also uses diesel generator. The diagram of the residential micro-grid is given in Figure 3.

\section{Simulation and Results}

The Nano-grid Operation data of the residential micro-grid is collected via either simulation, e.g. home software or time-logging. Power profiles of components in the residential micro-grid are then obtained. The PV power profile, wind power profile, residential load chart, and ESNG operation profile of one day is given in Figure 4. The calculation should be based on peak hours to run the system.

In past the SCADA system was used in the industry and it was wired system. there was major problem associated with this system was wired burnt out at high 


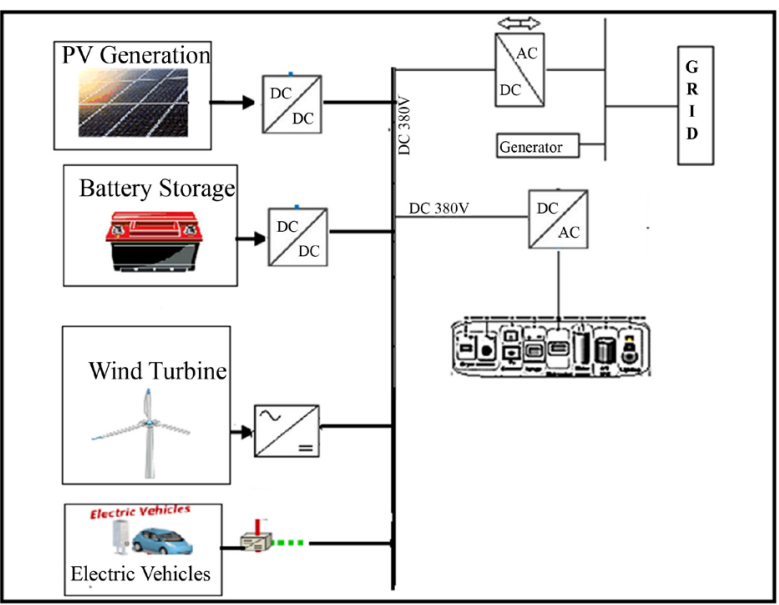

Figure 3. A residential micro-grids and with energy storage [4].

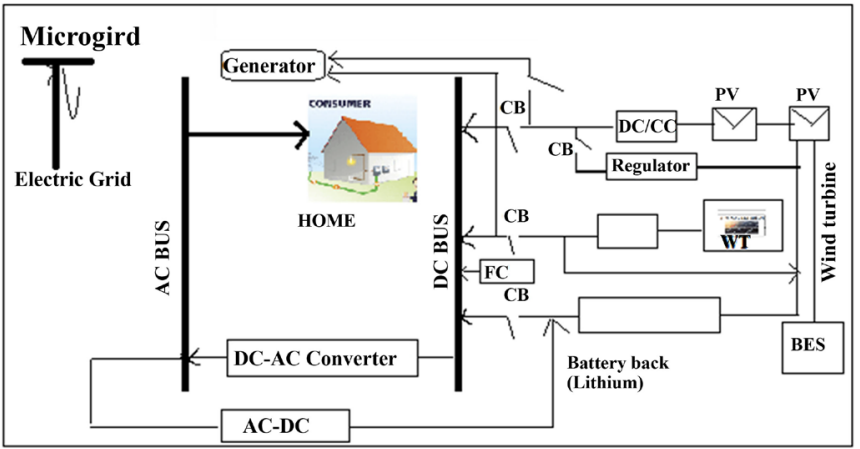

Figure 4. Model for Nanogrid.

temperature but by introducing wireless system and better insulation materials this problem is controlled. Now the system can send real-time commands to control the desired system wirelessly [6]. Today new power systems depend on computerized communications and control for options used cyber-physical systems is given in Figure 5. The SCADA system is presented for the controlling of wind farmpower.

However, ESNG profile does not simply show its pattern like residential load profile and PV profile. At same hour for different days, ESNG can be at its peak for charging, and imposingly at its valley for discharging. In Figure 6, below the small-scale Nano power system is given with small housing scheme. There are 9 load points, where the electricity has to provide to customer. In this system we are using solar power system for calculation. A matlab program was used for this system to calculate the efficiency of the system. The results are given in Figures 7(a)-(d).

In Figure 8, the Power profiles of components in residential micro-grid in first week of January for PV power profile and wind power profile for Residential load profile is given and ESNG profile to make Nano-grid reliable. For future power system wind power and fuel cell power will be added in this Nanogrid. The complete proposed solution for Nanogrid is given in Table 2. 


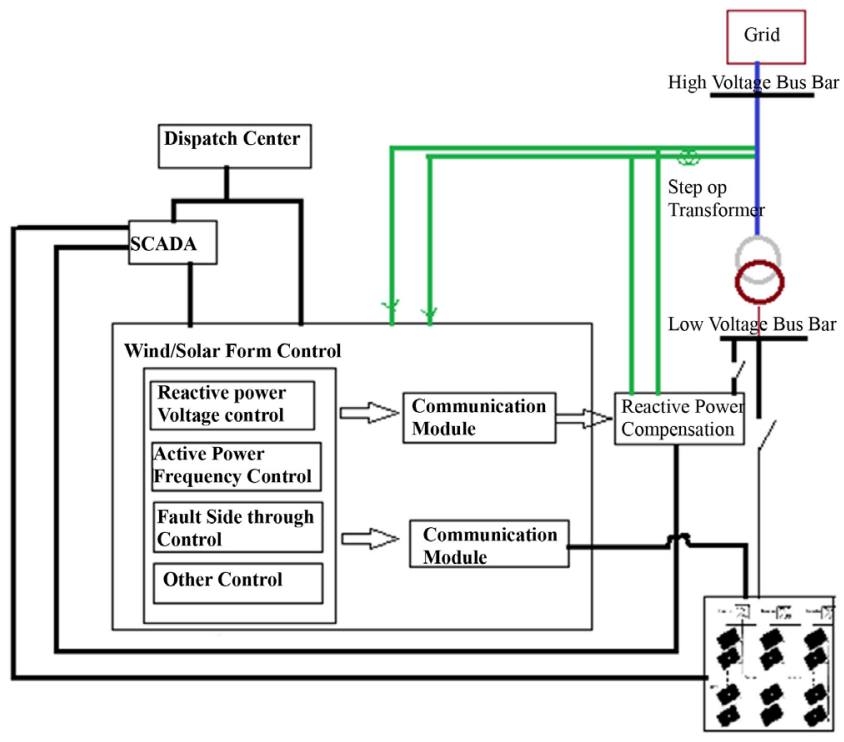

Figure 5. Module use for Nanogrid.

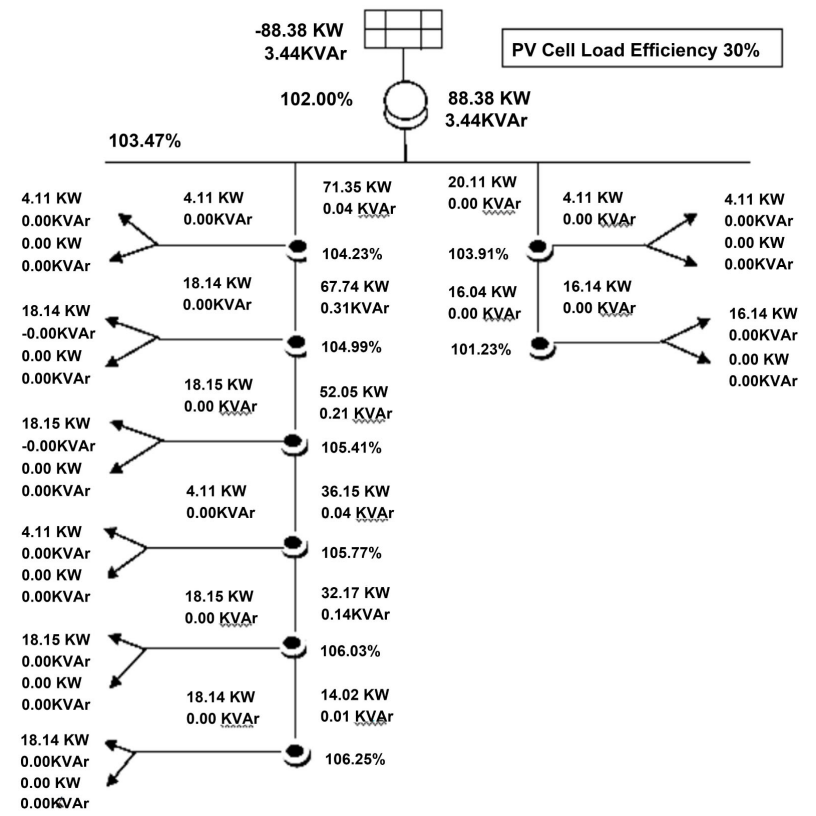

Figure 6. Load distribution for Nanogrid.

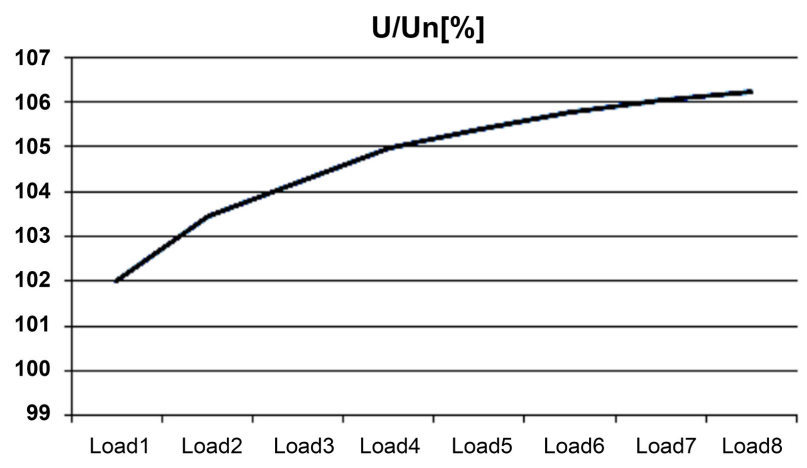

(a) 


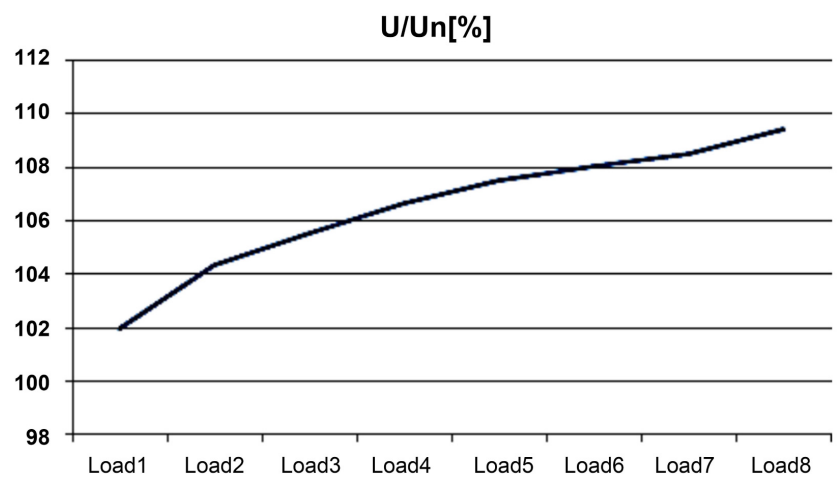

(b)

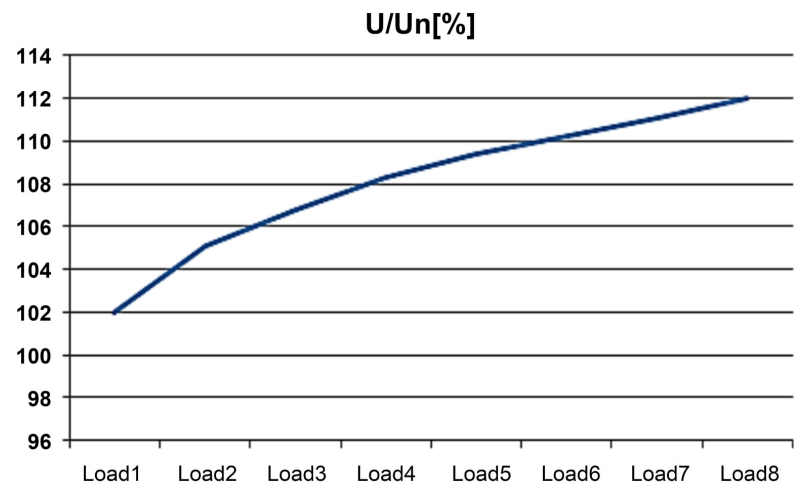

(c)

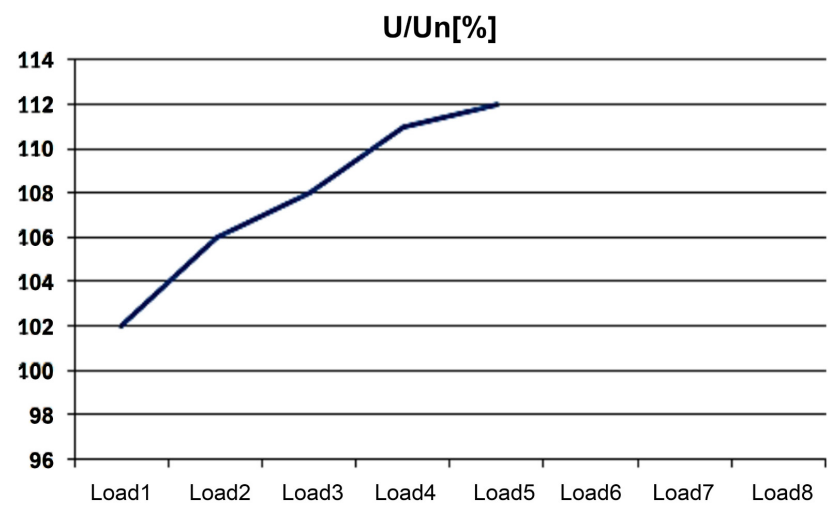

(d)

Figure 7. Power profiles of components in residential Nanogrid with load distribution efficiency for $30 \%, 50 \%, 70 \%$ and $100 \%$ with PV power system for Residential load profile.

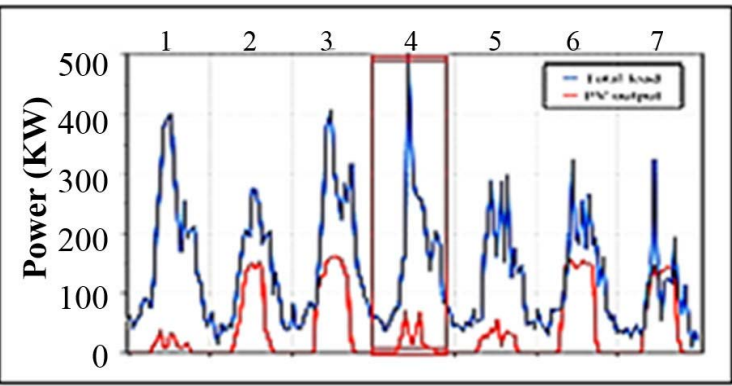

(a)

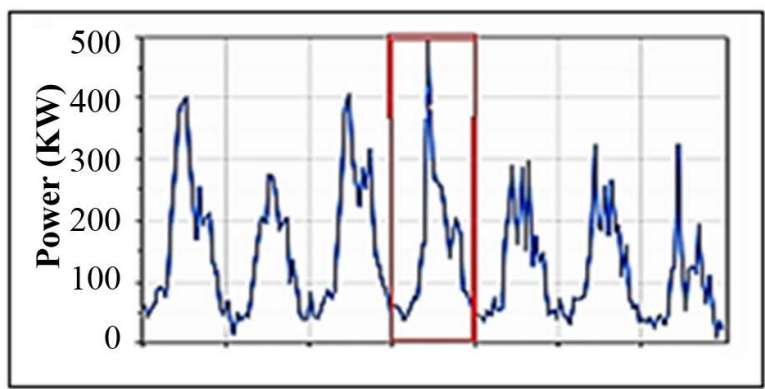

(b) 


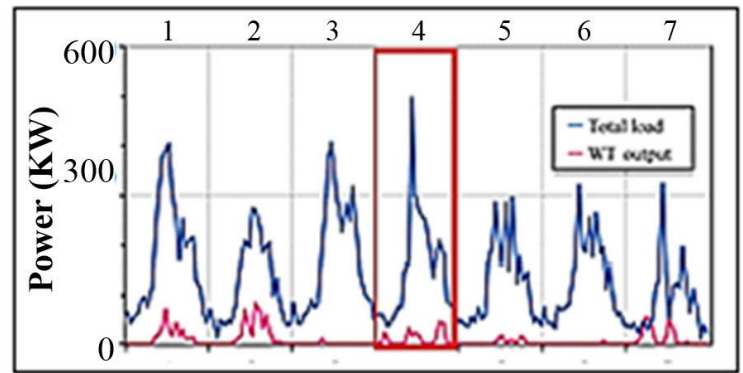

(c)

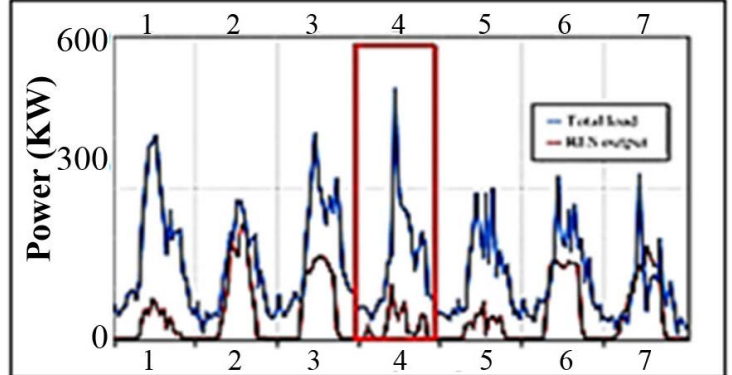

(d)

Figure 8. Power profiles of components in residential micro-grid in first week of January (a) PV power profile (b) Wind power profile (c) Residential load profile and (d) ESNG profile Make Nano-Grid reliable.

Table 2. The solution for Nanogrid issues.

\begin{tabular}{|c|c|c|c|}
\hline $\begin{array}{l}\text { Function of } \\
\text { grid storage }\end{array}$ & $\begin{array}{c}\text { Grid central storage } \\
\text { (Country) }\end{array}$ & $\begin{array}{l}\text { Distribution grid } \\
\text { storage (City) }\end{array}$ & $\begin{array}{l}\text { Customer end Storage } \\
\text { (House hold) }\end{array}$ \\
\hline $\begin{array}{c}\text { Balancing } \\
\text { demand and } \\
\text { supply }\end{array}$ & $\begin{array}{l}\text { Seasonal/weekly } \\
\text { fluctuations Large } \\
\text { geographical unbalances } \\
\text { Strong variability of wind } \\
\text { and solar (electricity and } \\
\text { gas storage need to be } \\
\text { integrated) }\end{array}$ & $\begin{array}{l}\text { Daily/hourly variations } \\
\text { Peak shaving (electricity } \\
\text { and heat/cold storage need } \\
\text { to be integrated) }\end{array}$ & $\begin{array}{l}\text { Daily variations (electricity } \\
\text { and heat/cold storage need } \\
\text { to be integrated) }\end{array}$ \\
\hline $\begin{array}{c}\text { Grid } \\
\text { management }\end{array}$ & $\begin{array}{l}\text { Voltage and frequency } \\
\text { regulation Complement to } \\
\text { classic power plants for } \\
\text { peak generation Participate } \\
\text { in balancing markets } \\
\text { Cross-order trading }\end{array}$ & $\begin{array}{l}\text { Voltage and frequency } \\
\text { regulation Substitute } \\
\text { existing ancillary services } \\
\text { (at lower } \mathrm{CO}_{2} \text { ) Participate } \\
\text { in balancing markets }\end{array}$ & $\begin{array}{l}\text { Aggregation of small } \\
\text { storage systems providing } \\
\text { grid services }\end{array}$ \\
\hline $\begin{array}{l}\text { Energy } \\
\text { Efficiency }\end{array}$ & $\begin{array}{l}\text { Better efficiency of the } \\
\text { global mix, with time shift } \\
\text { of off-peak into peak energy }\end{array}$ & $\begin{array}{l}\text { Demand side } \\
\text { management Interactions } \\
\text { grid end user }\end{array}$ & $\begin{array}{l}\text { Local production and } \\
\text { consumption Behavior } \\
\text { change Increase value of } \mathrm{PV} \\
\text { and local wind Efficient } \\
\text { buildings Integration with } \\
\text { district heating/cooling and } \\
\text { CHP }\end{array}$ \\
\hline
\end{tabular}

In Nanogrid components level we need systems which consumes low power and losses. The system work on two levels $360 \mathrm{~V}$ DC to $400 \mathrm{~V} \mathrm{DC}$ for nominal voltage and $380 \mathrm{~V} \mathrm{DC}$, for Low-voltage and $48 \mathrm{~V}$ to match the telecom voltage, computer loads and for low power LED lights.

Future power system based on decentralized system and home DC-based nonconventional Energy based System, which can be controlled power easily because we used storage system which reduces the electrical fluctuations in the system. It can be combination of wind, solar fuel cell energy and can work in stand-alone mode or it can connect to the main grid using smart switches for smooth transitions. Keeping above results in view we can say that DC based distribution is suitable for Nano-grids, many multi-port converter techniques has been recommended for Multi-port converters required [7]. 
The one big advantage of this system is that it is uses no breaker and less power converters.

\section{Conclusion}

This paper has presented the Nanogrid solution to storage issues, power control systems, soft switching with decentralized control strategy related to a DC Nano grid. The control strategy of the grid is presented by using a model of Nano grid and simulation program. It is analyzed that the operation of the decentralized power control strategy is suitable for Nano grid. The Nano grid model uses soft switching dynamics. In future, we need to implement Micro and Nano grids all country to fulfill the energy demands and proving clean energy to customers. In Pakistan, energy crisis and electricity are very expensive. We need to install this system on urgent basis. Future research will focus on building a low-power prototype Nanogrid to further verify the control strategy, and extending the Nanogrid model to account for transient phenomena.

\section{Acknowledgements}

Above all I will like to say thanks to almighty Allah for his countless blessings and thanks my father Dr. Zaki Ahmad (Allah give him Jannah) for his advice, guidance and support throughout his life. Finally, I will like to say thanks to all my friends for their inspiration and encouragement.

\section{Conflicts of Interest}

The authors declare no conflicts of interest regarding the publication of this paper.

\section{References}

[1] Mishra, S.K. (2013) Nanogrid DC Based Energy Distribution and Control. Indian Institute of Kanpar.

[2] Goyal, S. (2017) Nano Based Smart Homes with Electricity Production \& Trading Facility. International Journal of Innovative Research in Electrical, Electronic, Instrumentation and Control, 5.

[3] Mohan, N., Undeland, T. and Robbins, W. (2002) Power Electronics Converters, Applications and Design. John Wiley, New York, 19.

[4] Farret, F.A. and Simoes, M.G. (2006) Integration of Alternative Sources of Energy. John Wiley \& Sons.

[5] Masters, G.M. (2004) Renewable and Efficient Electric Power Systems. John Wiley \& Sons, Inc., Hoboken, 217-225, 230, 408-420.

[6] Kakigano, H., Miura, Y., Ise, T., Momose, T. and Hayakawa, H. (2008) Fundamental Characteristic of DC Microgrid for Residential Houses with Cogeneration System in Each House. IEEE Power \& Energy Society 2008 General Meeting, No. 08GM0500.

[7] Bryan, J., Duke, R. and Round, S. (2003) Distributed Generation-Nanogrid Transmission and Control Options. International Power Engineering Conference. 